\title{
Water quality change of rivers during rainy events in a watershed with different land uses in Southern Brazil
}

\section{Alteração da qualidade da água de rios em período chuvoso em bacia hidrográfica com diferentes usos do solo no Sul do Brasil}

\author{
Rubia Girardi ${ }^{1}$, Adilson Pinheiro ${ }^{1}$, Luis Hamilton Pospissil Garbossa ${ }^{2}$ and Édson Torres ${ }^{1}$ \\ ${ }^{1}$ Fundação Universidade Regional de Blumenau, Blumenau, SC, Brazil \\ ${ }^{2}$ Empresa de Pesquisa Agropecuária e Extensão Rural de Santa Catarina, Florianópolis, SC, Brazil \\ E-mails: ru.girardi@gmail.com (RG), pinheiro@furb.br (AP), garbossa@gmail.com (LHPG), ettotorres@gmail.com (ET)
}

Received: December 10, 2015 - Revised: March 14, 2016 - Accepted: March 25, 2016

\begin{abstract}
High frequency monitoring in environmental studies is increasingly being used due to the availability of equipment and quick response. With high frequency time series, it is possible to extract short-term responses during and after a rain event, which is not captured by conventional monitoring. The aim of this study is to evaluate the superficial water quality change of a stream in a preserved area in Atlantic Forest by short-term data (hour interval). The Cubatão do Sul watershed is located in the Central Coast region of the state of Santa Catarina in Brazil. Rain height and water quality parameters were monitored using rain gauge and multiparameter probes. Two fluviometric sections were also monitored — one in Vargem do Braço stream (FS1), which is mainly native forest (dense ombrophilous forest), and the other in Cubatão do Sul River (FS2), which is influenced by urban, agricultural and sand extraction uses. The temperature and nitrate ion permanency curve in FS1 showed slightly lower values during rainy events, but an opposite behavior was observed for turbidity. On the other hand, the permanency curves during rainy periods of FS2 presented lower conductivity and ammonium ion. When the dry and rainy periods were statistically compared, there was a significant difference for temperature, conductivity, $\mathrm{pH}$, nitrate ion, turbidity and dissolved oxygen for FS1, and temperature, conductivity and turbidity for FS2. The water quality of the Cubatão do Sul watershed is influenced by stream flow and has a short-term time response considering the rain events. The oscillation of the monitored parameters between two periods, dry and rainy, is smaller in native forest than urban and rural land use.
\end{abstract}

Keywords: Atlantic Forest; Serra do Tabuleiro; High frequency monitoring; Background area.

\section{RESUMO}

O monitoramento ambiental de alta frequência está sendo cada vez mais utilizado, devido à disponibilidade de equipamentos e pela resposta rápida gerada. As séries temporais de alta frequência mostram que as respostas de curto prazo, durante e após a ocorrência de chuva não são capturados por programas de monitoramento convencionais. Este trabalho teve por objetivo a avaliação da alteração da qualidade da água de escoamento fluvial em uma bacia hidrográfica em unidade de conservação no bioma Mata Atlântica, com resposta de curto prazo, devido a ocorrência de evento de chuva, monitorado em intervalo de tempo horário. A Bacia do Rio Cubatão do Sul localiza-se na zona Litoral Centro de Santa Catarina, Brasil. Foram monitorados a altura de chuva, por meio de pluviógrafo e parâmetros de qualidade das águas, com o uso de sondas multiparâmetros. Foram monitoradas duas seções fluviométricas, uma no rio Vargem do Braço (FS1), que localiza-se em situação praticamente natural, com predominância de Floresta Ombrófila Densa e outra no rio Cubatão do Sul (FS2) que possui influência de área urbana, agrícola e extração de areia. As curvas de permanência da temperatura e do íon nitrato na FS1 apresentaram valores levemente inferiores no período chuvoso, comportamento oposto foi observado na turbidez. As curvas de permanência da FS2 apresentaram diminuição da condutividade elétrica e íon amônio nos períodos chuvosos. Quando foram comparados os períodos secos e chuvosos estatisticamente, constatou-se diferença para os parâmetros temperatura, condutividade elétrica e turbidez na FS2 e temperatura, condutividade elétrica, $\mathrm{pH}$, nitrato, turbidez e oxigênio dissolvido na FS1. Assim, constatou-se que a qualidade da água da bacia hidrográfica do rio Cubatão do Sul é influenciada pelo escoamento fluvial e possui 
tempo de resposta de curto prazo, em decorrência de evento de chuva. Adicionalmente, o uso do solo influenciou nas alterações da qualidade da água em decorrência de evento de chuva. A oscilação entre os valores mensurados dos parâmetros nos dois momentos é menor em área preservada com mata nativa do que aquela com uso do solo com ocupação urbana e rural.

Palavras-chave: Mata Atlântica; Parque Estadual Serra do Tabuleiro; Monitoramento de alta-frequência; Unidade de conservação.

\section{INTRODUCTION}

High frequency environmental monitoring is increasingly being used due to the availability of equipment and for the quick response generated. Instruments such as multiparameter probes measure the water quality and can make samples in short intervals, either in an order of hours or minutes (AUBERT et al., 2014; HALLIDAY et al., 2015; TERCIER-WAEBER et al., 2009; WADE et al., 2012). The multiparameter probes have aided in complex evaluation of the dynamics of nutrients (HALLIDAY et al., 2014) and in the behavioral description of biogeochemical cycles of chemical species in water bodies (HALLIDAY et al., 2015; MORAETIS et al., 2010; WADE et al., 2012).

Different land uses, such as urban and rural, can change the natural hydrological regime of water bodies and degrade their quality (BRION et al., 2011). High frequency monitoring of rivers is being performed to compare hydrological and chemical standards in watersheds with different land uses (NEAL et al., 2010; OUTRAM et al., 2014; WADE et al., 2012).

The high frequency time series shows that the short-term response, during and after the occurrence of rain, is not captured by conventional monitoring programs that adopt low frequency measurements (NEAL et al., 2012). Therefore, high frequency monitoring has been used to evaluate changes in water quality caused by rainfall events (BIEROZA; HEATHWAITE, 2015; CASSON; EIMERS; WATMOUGH, 2014; SARACENO et al., 2009).

High frequency monitoring of watercourses has been conducted in many parts of the world, such as China, United States, United Kingdom and other European countries. Latin America is still lacking this kind of work. Brazil has two important rainforests - the Amazon and the Atlantic Forest. The Atlantic Forest is one of the 25 global hotspots for biodiversity conservation (MYERS et al., 2000). The increase in the rate of deforestation in the Atlantic Forest in São Paulo and in Brazil's South could lead to the loss of a unique diversity location and the destruction of the historical processes signature that led to it. This would prevent the understanding of the underlying mechanisms of the local endemism and prevent the most effective conservation measures (CARNAVAL et al., 2009). In addition, the conservation of native forests is essential for generating water (ALMEIDA; BENASSI, 2015).

Therefore, it is important to study the coupling between the frequent rains in these biomes and the water quality of its rivers. This study aimed to evaluate the change in the river flow water quality in a watershed in two fluviometric sections in the conservation area of the Atlantic Forest biome, with short-term response, faced to the occurrence of rain events, monitored in time interval.

\section{MATERIALS AND METHODS}

The study area is the watershed of Cubatão do Sul River, which flows through the cities of Águas Mornas, Santo Amaro da Imperatriz, part of São Pedro de Alcantara and Palhoça, located on the Atlantic side of the Central Coast of Santa Catarina, Brazil. The Cubatão do Sul River is the main watershed, with a total length of $62 \mathrm{~km}$. The Vargem do Braço and Cubatão do Sul Rivers are the capture of water sources of five cities in the region. The watershed has a $746 \mathrm{~km}^{2}$ drainage area, and $46 \%$ of the area is inserted in the Parque Estadual da Serra do Tabuleiro. The predominant types of soil are inceptisol (56.6\%) and alfissol (24.8\%). The climate, according to Köppen classification, is defined as a transition between Cfa (humid temperate climate with hot summers) and $\mathrm{Cfb}$ (humid temperate climate with temperate summer. Annual rainfall is between $1220 \mathrm{~mm}$ and $1660 \mathrm{~mm}$ with the absence of a dry period (CURTARELLI, 2009; KOBIYAMA; CHAFFE, 2008; SERGIO; FRANCO; GARBOSSA, 2013).

The height of rainfall and water quality parameters were monitored. The rain height was measured at the station ETA CASAN Montante of the Agência Nacional de Água (ANA), Figure 1, with the rain gauge WaterLog ${ }^{\circledR}$ brand of folding type, with compensation depending on the intensity of the rain. This model has an internal microprocessor that measures the frequency of the folding movement to calculate the rain height using a calibration curve with rainfall intensity. The rainfall station is located at an altitude of $12 \mathrm{~m}$, at latitude $27^{\circ} 41^{\prime} 3290^{\prime \prime}$ and longitude 48 42’39 50" (Datum WGS 84). The instrument is set to read at hourly intervals, and the data are stored in a data logger and transmitted to the ANA.

Water quality parameters were measured in two fluviometric sections - one in the Vargem do Braço River (FS1) and another on the Cubatão do Sul River (FS2). The use and occupation of FS1 and FS2 are shown in Table 1, and the spatial distribution of the soil use is shown in Figure 1. In both fluviometric sections of the basin were installed multiparameter probes, Hydrolab DS5X model. These devices used ion-selective electrodes for ammonium $\left(\mathrm{NH}_{4}^{+}\right)$and nitrate $\left(\mathrm{NO}_{3}^{-}\right)$ion, only in FS1; an optical sensor for dissolved oxygen and turbidity; and potentiometric for hydrogen potential $(\mathrm{pH})$ and electrical conductivity. The sampling was carried out hourly. The measurement and calibration probes were made with standard solutions time interval from 30 days, sometimes, until 60 days.

FS1 is located in the Vargem do Braço River, which is a tributary of the Cubatão do Sul River (Figure 2), located at an altitude of $259 \mathrm{~m}$, at latitude $27^{\circ} 44^{\prime} 1312^{\prime \prime} \mathrm{S}$, and longitude $48^{\circ}$ 45’24 97' W (Datum WGS 84), and has $131.21 \mathrm{~km}^{2}$ of drainage area. The upstream of this fluviometric station is in a wild land, almost in a natural situation, especially in an ombrophilous dense forest. The area is entirely contained in the Serra do Tabuleiro 


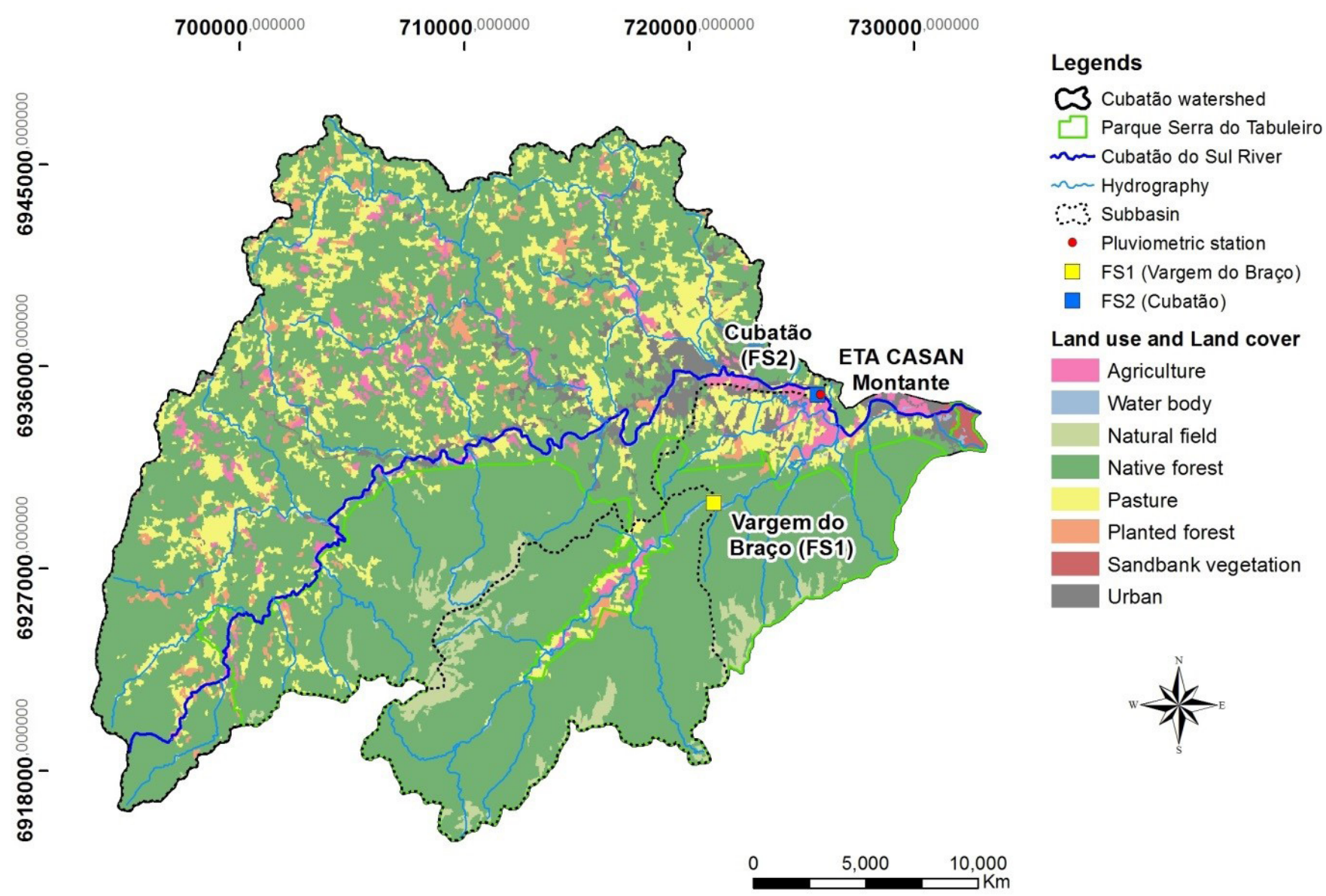

Figure 1. Land use in Cubatão River watershed.

Table 1. Land use of the upstream of FS1 and FS2.

\begin{tabular}{lrrrrr}
\hline \multirow{2}{*}{\multicolumn{1}{c}{ ass }} & \multicolumn{2}{c}{ FS 1 } & & \multicolumn{2}{c}{ FS 2 } \\
\cline { 2 - 3 } \cline { 5 - 6 } \cline { 5 - 6 } & $\mathbf{k m}^{\mathbf{2}}$ & \multicolumn{1}{c}{$\mathbf{0}$} & & $\mathbf{k m}^{\mathbf{2}}$ & $\mathbf{\%}$ \\
\hline Natural field & 10.68 & 8.14 & & 5.36 & 1.08 \\
Pasture & 3.84 & 2.92 & & 78.93 & 15.98 \\
Planted forest & 0.86 & 0.65 & & 12.74 & 2.58 \\
Atlantic forest & 113.40 & 86.44 & & 357.90 & 72.43 \\
Water body & 0.99 & 0.75 & & 2.47 & 0.50 \\
Agriculture & 1.42 & 1.08 & & 14.92 & 3.02 \\
Urban & 0.03 & 0.02 & & 21.77 & 4.41 \\
Total & 131.21 & 100 & & 494.09 & 100 \\
\hline
\end{tabular}

Park. The park is the home of a large biodiverse area and has $841.30 \mathrm{~km}^{2}$ (FATMA, 2015).

FS2 is implanted on the Cubatão do Sul River (Figure 2), located at an altitude of $11 \mathrm{~m}$, at latitude $27^{\circ} 41^{\prime} 3388^{\prime \prime} \mathrm{S}$ and longitude $48^{\circ} 42^{\prime} 39$ 38' W (Datum WGS 84), and has an upstream drainage area of $494.04 \mathrm{~km}^{2}$. This upstream region is in an area that has influence of agriculture, pasture, urban and sand extraction (Figure 1). The Cubatão do Sul River drains the cities of Águas Mornas and Santo Amaro da Imperatriz before reaching the fluviometric section. These cities have a total population of 27,000 inhabitants and extensive agricultural activities. Agricultural crops are predominantly temporary, the main agricultural crops are tomato $(5500 \mathrm{~T})$, sugar cane $(4550 \mathrm{~T})$, cassava $(3300 \mathrm{~T})$ and onion (1200 T) (IBGE, 2015). The tomato is a demanding crop in fertilizer, and the application varies around 80-120 kg.haof the N (EMBRAPA, 2006). The Santo Amaro da Imperatriz region has thermal springs and a tourist infrastructure to use this natural resource.

The rain events that occurred between 2012/01/06 and 2013/02/06 were selected based on the data generated by the rain gauge. In this data set, the rainy and dry periods were separated for FS1 and FS2. Each data group was related to temperature, electrical conductivity, $\mathrm{pH}$, ammonium ion, nitrate ion, turbidity and dissolved oxygen. The periods considered as rainy were the ones with a value equal to or greater than $0.2 \mathrm{~mm}$, with ranges up to $3 \mathrm{~h}$ without rainfall, preceded and succeeded by the occurrence of rain. Dry periods were accounted for with rain records equal to zero. Isolated values of $0.2 \mathrm{~mm}$ of precipitation were not considered, which may be attributed to dew condensation or high humidity in the environment.

In order to enhance the comparison of retention curves between fluviometric sections and to reduce possible mistakes, five values were excluded from a sample of 6,014 values of ammonium ion concentration in the FS2 which were between 14.26 and $20.96 \mathrm{mg} \cdot \mathrm{L}^{-1}\left(\mathrm{NH}_{4}^{+}\right)$. All remaining values were less than $5.64 \mathrm{mg} . \mathrm{L}^{-1}\left(\mathrm{NH}_{4}^{+}\right)$. In addition, some of the electrical 
conductivity as a function of probe calibration loss in isolated moments were excluded.

To check the frequency of occurring rainfall in the region and the values for each parameter, quality retention curves were traced. The retention curve describes the relationship between the frequency of occurrence of the parameter as bigger than or equal to the ordinate value y-axis. The procedure for obtaining the curve was based on the frequency analysis data associated with each parameter. Then, the length of curve was obtained and showed the values of each parameter on the ordinate axis and the cumulative frequency on the axis of abscissa (PRUSKI et al., 2014).

The normality of groups generated by the separation of dry and wet periods by the Shapiro-Wilk test was tested with a 95\% significance level. All parameters found a nonparametric distribution, and the Wilcoxon test was applied to compare the groups. The paired test was used to compare the dry and rainy period in the Cubatão do Sul River and the Vargem do Braço River. To compare the dry and rainy periods in each river, the Wilcoxon test with independent variables was used. We note that there is only a difference between the groups when the $\mathrm{P}$ value of 0.05 is less than the stipulated confidence level.

The comparison of the generated data set, median, lower and upper limits parameters of water quality in each group - dry and rainy, Cubatão do Sul River and Vargem do Braço — was graphically built as a Boxplot type. In the diagrams, different small
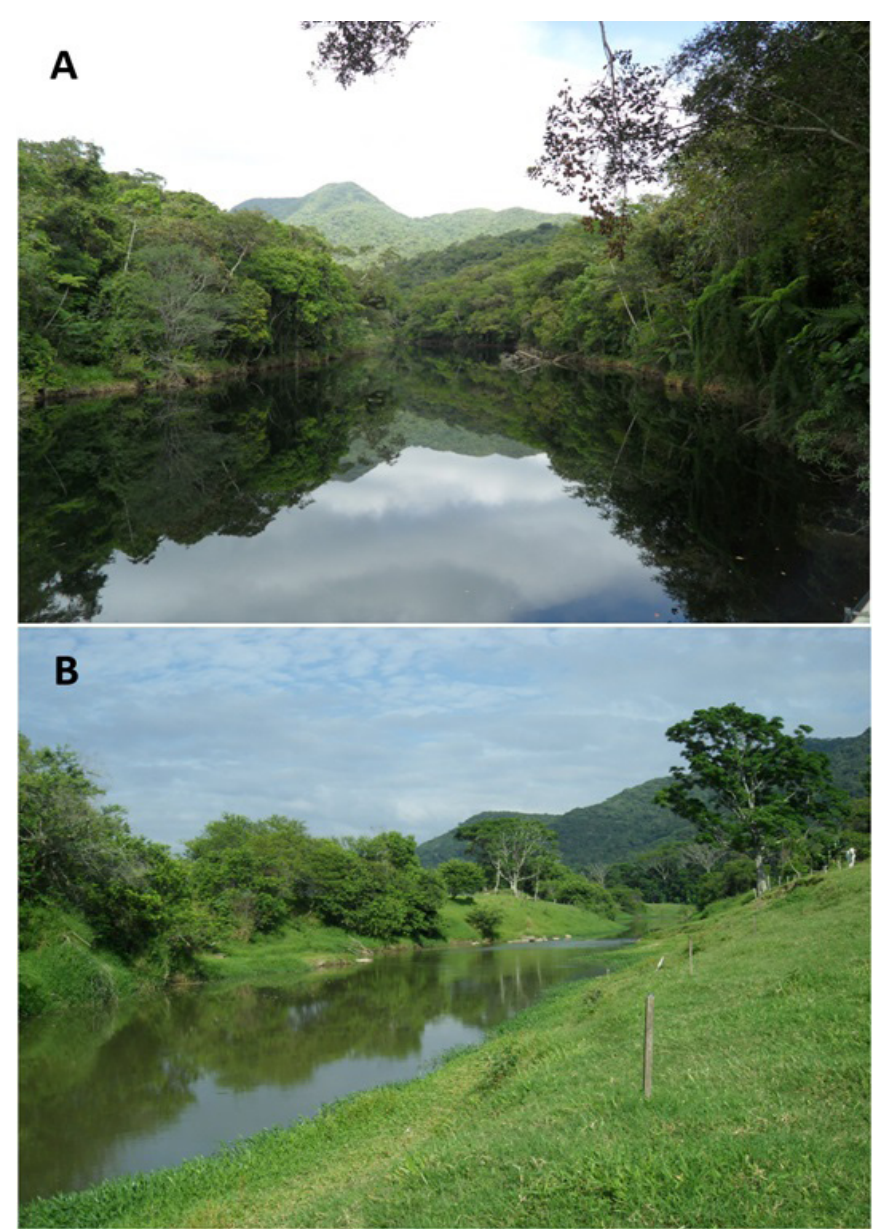

Figure 2. FS1 (A) upstream and FS2 (B) downstream. letters indicate the existence of a statistically significant difference $(\mathrm{P}<0.05)$, therefore, equal letters show that there is no statistical difference between the groups. All statistical tests were performed using Excel with the use of the supplement Action.

\section{RESULTS AND DISCUSSION}

The height and frequency of rainfall in the study period can be evaluated in Figure 3. Note that the heights of rains are low, with short periods of return, when applied to the IDF equations (Intensity Duration and Frequency), established by Back (2002).

The temperature duration curves in FS1 and FS2 (Figure 4A and 4B) do not show extreme values, except in the dry period of FS2, where minimum temperatures reaching $7.7^{\circ} \mathrm{C}$ are found. The temperature and nitrate ion in FS1 were slightly lower in the rainy period when compared to the dry period (Figure 4A and 4I). The opposite behavior was observed for turbidity, which showed maximum turbidity in FS1 of 572 NTU and FS2 1,229 NTU (Figure 4J and 4K).

When comparing the dry and rainy periods of FS2, it is clear that this section had decreased electrical conductivity, average from 103.7 to $89.7 \mu \mathrm{S} . \mathrm{cm}^{-1}$, and diminish concentration of ammonium ion, average from 2.14 to $2.00 \mathrm{mg} \cdot \mathrm{L}^{-1}$ (Figure $4 \mathrm{D}$ and $4 \mathrm{H}$ ). The evolution of the turbidity values, both in FS1 and in FS2, had similar behavior, showing a small increase in the rainy period (Figure 4J and 4K). This increase was, on average, 6.4 to $8.3 \mathrm{NTU}$ in FS1, and 41.7 to 48.4 NTU in FS2.

Dissolved oxygen presented minimum values well marked in the rainy period, of 6.73 and 7.97 for FS1 and FS2, respectively, and for FS2 in the dry period, $6.87 \mathrm{mg} . \mathrm{L}^{-1}$, except for FS1 in the dry period (Figures 4L and 4M). In FS2, the permanence curve showed maximum and minimum values clearly visible. The concentration of dissolved oxygen showed adverse developments in the two fluviometric sections. While in FS2, the lowest values appear in the dry period, in FS1 they are in the rainy period.

The electrical conductivity and the concentration of ammonium ion FS2 showed much bigger oscillation than in FS1, both in the dry and rainy periods (Figures 4C, 4D, 4G and 4H). In FS1, lower $\mathrm{pH}$ values, with a minimum 4.6, appear in the rainy period, while in FS2 the $\mathrm{pH}$ values are at a minimum 5.22 during the dry period (Figures $4 \mathrm{E}$ and $4 \mathrm{~F}$ ).

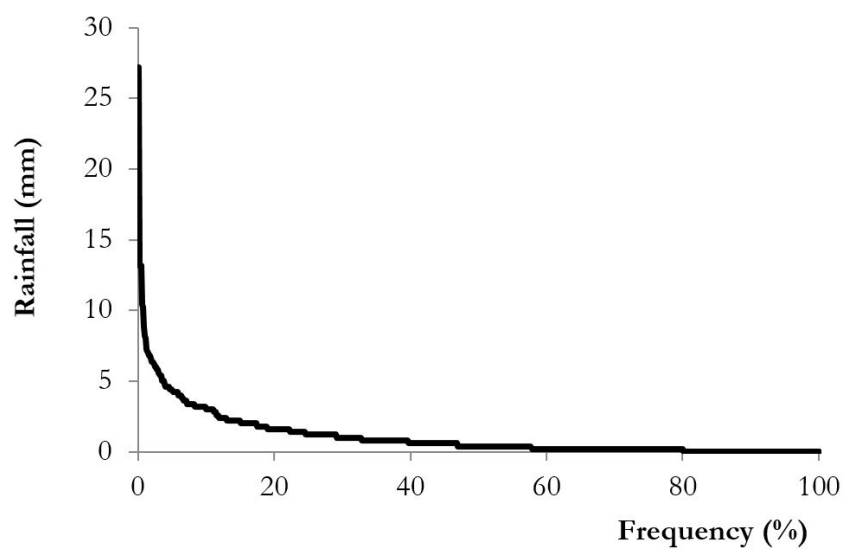

Figure 3. Rain permanence curve. 

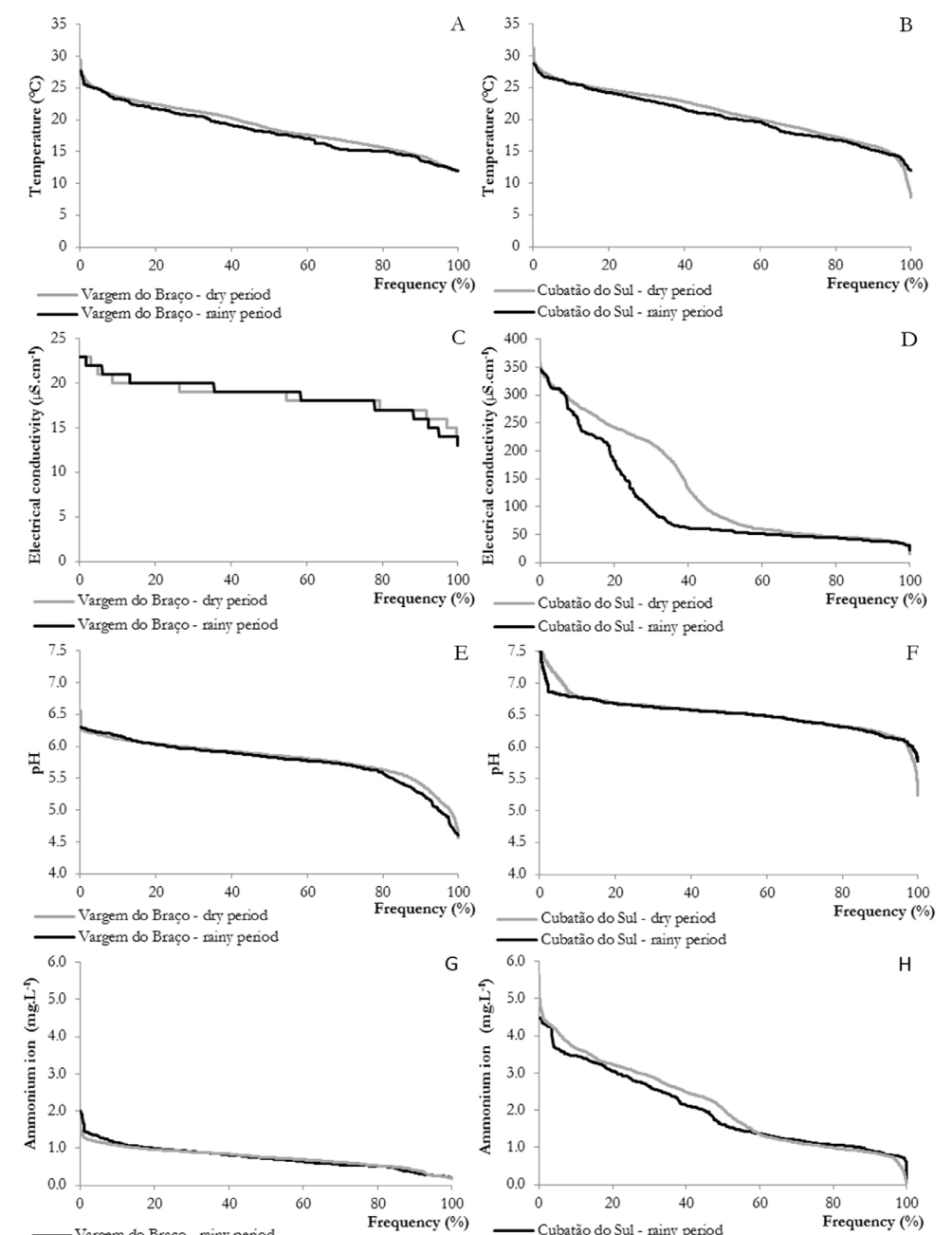

G
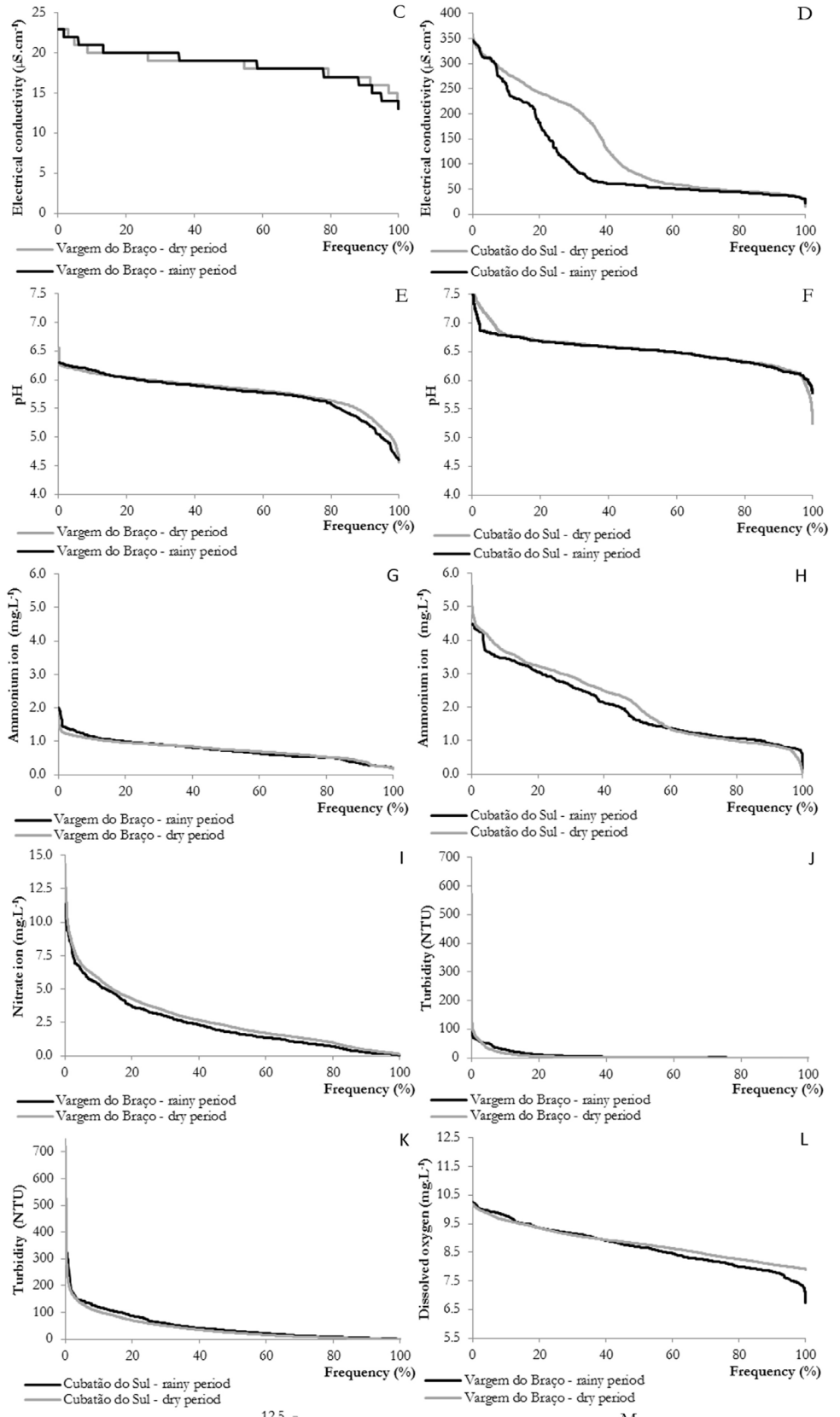

ZCubatão do Sul - rainy period

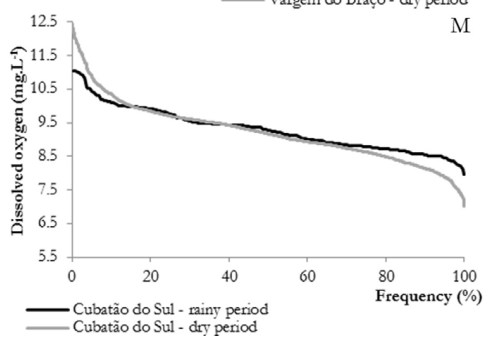

Figure 4. The duration curve of the parameters measured in the dry and wet periods for FS1 (A, C, E, G, I, J, L) and FS2 (B, D, F, $\mathrm{H}, \mathrm{K}, \mathrm{M})$. 
Comparing the dry and wet periods of FS2, it was found that there was no statistical difference for the parameters of temperature, electrical conductivity and turbidity (Figure 5). In FS1, a statistical difference occurred in temperature, electrical conductivity, $\mathrm{pH}$, nitrate ion, turbidity and dissolved oxygen. In the comparison of the rainy and dry periods between FS1 and FS2, it is clear that there are differences in all parameters. P values found in the comparison between the two rivers, in dry periods and rainy, were very low, tending to zero.

Evaluating the temperature values measured by the probe during the dry and rainy periods, we noticed that in FS1 and FS2 there was a narrowing of the range of the upper and lower temperatures (Figure 5A). In FS2 when comparing the dry and wet periods, respectively, the maximum temperature decreased from $31.2^{\circ} \mathrm{C}$ to $28.7^{\circ} \mathrm{C}$ and a minimum rose from $7.7^{\circ} \mathrm{C}$ to $12.0^{\circ} \mathrm{C}$, whereas in FS1 the minimum increased from $11.5^{\circ} \mathrm{C}$ to $12{ }^{\circ} \mathrm{C}$ and maximum decreased from $29.4^{\circ} \mathrm{C}$ to $27.7^{\circ} \mathrm{C}$ (Figure $5 \mathrm{~A}$ ). Temperatures in the present FS1 are lower than in FS2.

The temperature showed a downward trend as a result of rain (Figures 4A and 4B), in addition, there was a decrease of the temperature amplitude during rainy periods (Figure $5 \mathrm{~A}$ ). At the beginning of the rainfall event, due to the reduction of solar rays and the presence of frequent cold fronts, there is a tendency for temperature reduction in the environment, which after a time interval is reflected in rivers. Saraceno et al. (2009) worked with high frequency monitoring in situ in a rural watershed in California and reported that the temperature of the river presented diurnal variability before and after an intense rain event, and daytime values were reduced during the period of heavy rains. However, the environmental temperature amplitude is decreased, while there is an increase of humidity caused by rain. Possibly this fact influenced the diminution of limits found during the rainy period.

FS1 and FS2 showed differences in the distribution of temperature values for dry and wet periods (Figure 5A). The FS1 input area is situated in a preserved area with forest cover, which contributes to the formation of a microclimate. Rex et al. (2012). who worked with air temperature and water sub-boreal headwater streams in British Columbia, stated that raising the environmental temperature was the result of more open canopy that allowed solar radiation intercepts to heat the soil. Then, in locations with more closed canopy, as in FS1, there is less solar heat trapped in the soil and less temperature variation. Additionally, the maximum water temperatures remained significantly higher in places where there was suppression of riparian vegetation, as in FS2, than the places where it has remained.

In FS2, the electrical conductivity impacted by rain reduced

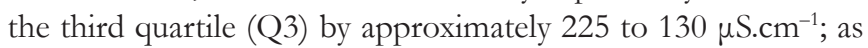
well as the median of 75 to $60 \mu \mathrm{S} . \mathrm{cm}^{-1}$ (Figure 5B); although there was an increase in the upper limit. This behavior can be attributed to the dilution effect, that is, the water that was coming to the river had lower conductivity, causing dilution of the ions and in the polar molecules in the watercourse.

In the Vargem do Braço River, there is also a statistical difference in electrical conductivity between the rainy and dry periods (Figure 5B). The FS1 has very low levels of electrical conductivity when compared to the FS2, both in the dry period and rainy. The FS2 contribution area has use of the most varied soil with influences from urban areas, pasture and agriculture. In urban areas, there may be the release of sewage rich in nutrients that will contribute to the increase of the conductivity of water compared to FS1. Andrade et al. (2011) found that the water of an urban stream presented significant differences from the water of a stream area with minimal disturbance in the Atlantic Forest. They found high carbon dioxide concentrations dissolved, inorganic nitrogen and dissolved inorganic carbon, and attributed these differences in the water quality to the anthropogenic impact, especially the discharge of domestic sewage.

In addition, rural areas near the FS2 can increase the electrical conductivity of the river waters through the transport of ionic compounds used in agriculture, such as potassium, phosphorus and nitrogen. Viswanathan, Molson and Schirmer (2015) found the highest values of electrical conductivity in the summer period, giving the rich soil solution accumulated solutes and captured during recurrent rains this time of year.

The FS1 suffered subtler change in the electrical conductivity due to the rain. Brion et al. (2011) reported that the electrical conductivity of a stream can change significantly depending on the land use, even over short distances of $300 \mathrm{~m}$. In this particular case, it is a river and its tributary, and each section has different use of soils. FS1 is contained in a state park, with little influence of agriculture, pasture and urbanization — very different from FS2.

In rainy periods, the $\mathrm{pH}$ in FS1 showed subtle decrease the lower limit, median and first and third quartile, as compared to the dry period of the same river (Figure 5C). In FS2, the $\mathrm{pH}$ suffered a small decrease in the upper limit of 7.2 to 7.1 , without generating a statistical difference between the groups. The $\mathrm{pH}$ in FS1, both in the rainy and dry periods, showed values lower than FS2.

FS2 showed no change in $\mathrm{pH}$ in the rainy and dry periods (Figure 5C). This fact can be attributed to the events with low levels of rain that were found, in which the intensity may not be enough to generate the superficial Hortonian runoff and cause changes in water quality.

The $\mathrm{pH}$ of FS1 was lower than in FS2 in all studied periods. Working with riparian areas of soil in China, Xi et al. (2015) found a negative correlation between $\mathrm{pH}$ and dissolved organic carbon derived from the decomposition of organic matter present in the leaf litter. Consequently, increasing destruction of riparian areas raised the $\mathrm{pH}$ of the soil of that region. We could relate in FS2 the removal of the forest for agriculture, grazing and urbanization with increasing soil $\mathrm{pH}$ of this section in relation to FS1.

Additionally, Diniz et al. (2013) analyzed internal precipitation in a secondary forest in an advanced stage of the Atlantic Forest and found $\mathrm{pH}$ of 6.5 , which may contribute to the decrease in $\mathrm{pH}$, since runoff water may have slightly acidic $\mathrm{pH}$.

FS1 showed a tendency to decrease its $\mathrm{pH}$ after rain events, occurring differently between wet and dry periods (Figure 5C). Possibly the $\mathrm{pH}$ reduction occurred due to superficial runoff and subsurface generated by rain, which leaches materials rich in organic acids, such as fulvic acid, resulting from decomposition of the leaf litter. Fujii et al. (2011) found that acidic soil solutions extracted from the Indonesian rain forest and organic acids as dominant anions in the solution removed the first layer of soil. This proposal also explains why the pH of FS1 is lower than FS2. 
A

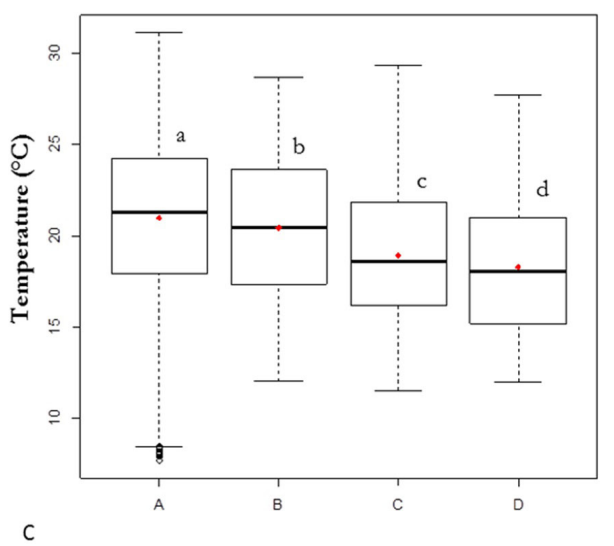

C
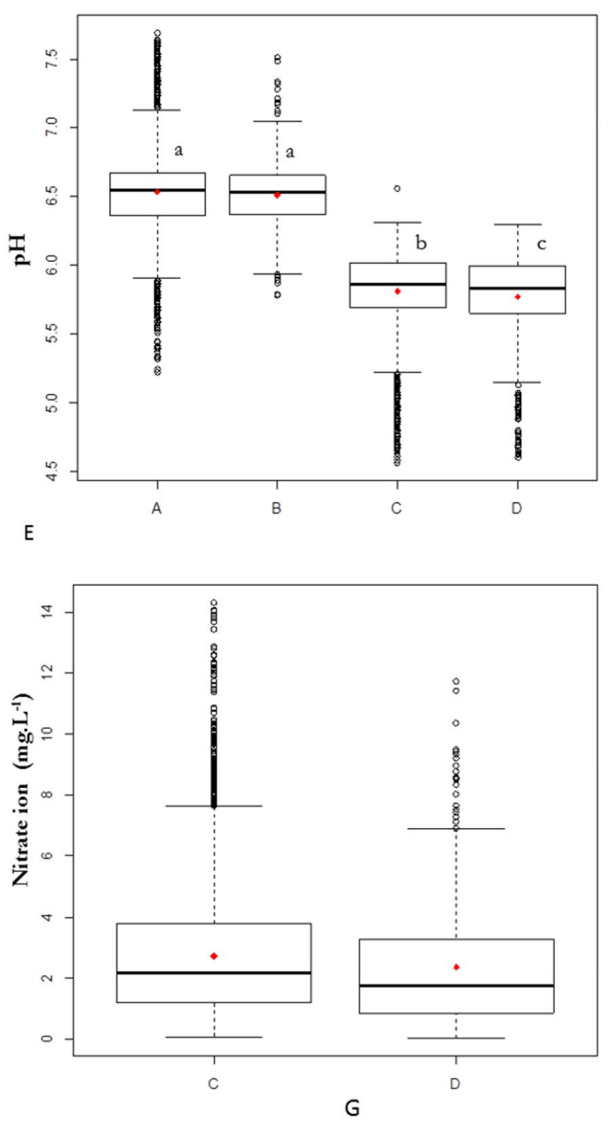

B
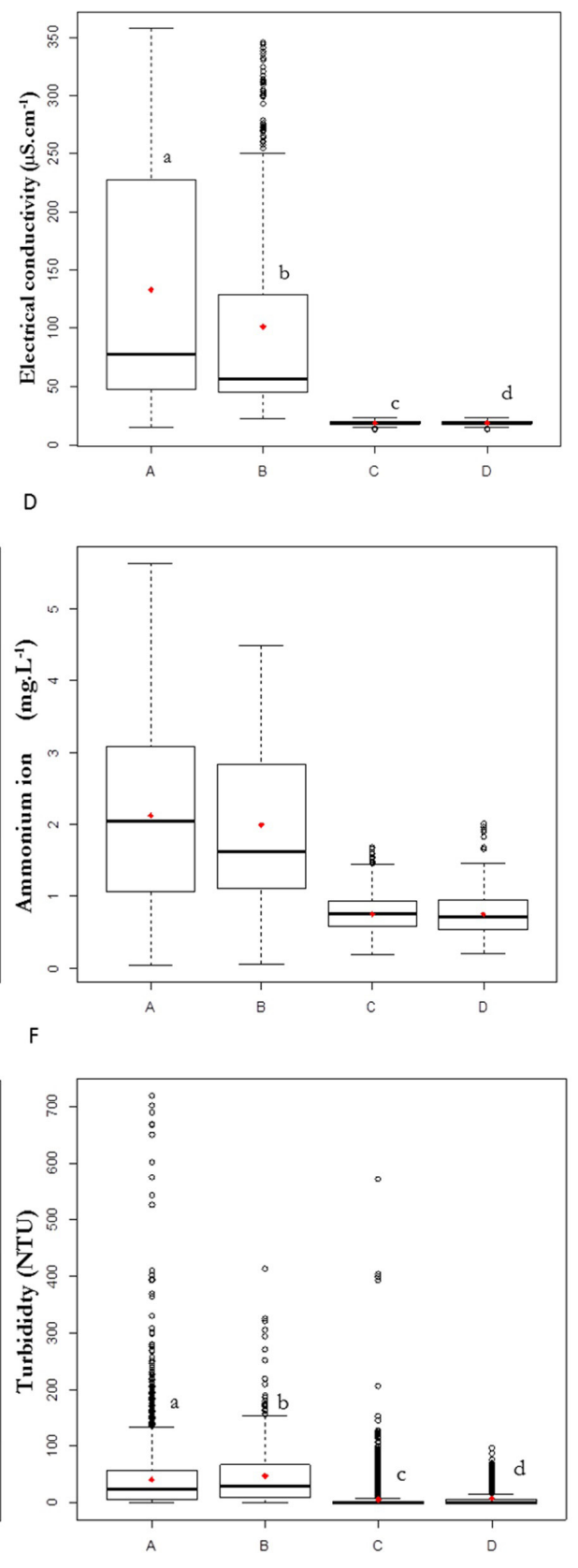

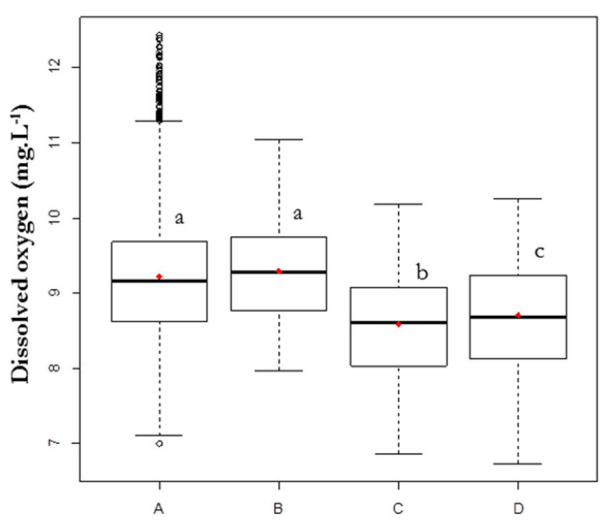

Figure 5. Box plot of FS2 in the dry period (A) and rainy (B), and FS1 in the dry period (C) and rainy (D). Different lowercase letters, above diagrams, indicate the existence of statistically signifiant difference $(\mathrm{P}<0.05)$. 
Additionally, Miranda, Canellas and Nascimento (2007) worked with Atlantic Forest fragments and detected low $\mathrm{pH}, 4.4$, in soil samples from $0-10 \mathrm{~cm}$ profile.

In FS2, the concentration of ammonium ion decreased in rainy periods, demonstrated by the lowering of the upper limit from 5.5 to $4.5 \mathrm{mg} . \mathrm{L}^{-1}$ and the median of 2.1 to $1.8 \mathrm{mg} . \mathrm{L}^{-1}$, although there was no statistical difference (Figure 5D). In the concentration of ammonium ion in FS1 there was also no difference between the rainy and dry periods (Figure 5D). The only difference was found between concentrations of ammonium ion in FS1 and FS2 in the dry and rainy periods.

The ammonium ion in FS1 can be from the leaf litter, where there is the breakdown of proteins and nucleic acids rich in nitrogen compounds. This material can reach the river through runoff and be leached in subsurface runoff. Riaz, Mian and Cresser (2011) demonstrated the importance of leaf litter in ammonium leaching through the decrease of mineral nitrogen during the summer months in a prairie acid soil.

In FS2, beyond the influence of forest areas, there is also the contribution of agriculture and pasture, with the application of fertilizers and the contribution of animal waste and urbanization with the discharge of domestic effluents. Probably for these reasons, FS2 showed higher values of ammonium ion than FS1. Kamjunke et al. (2013) worked with the biogeochemical analysis of an entire river network in Germany, whose land use was divided into $23 \%$ of forested areas of the "National Park," $70 \%$ of agriculture and $7 \%$ of urban areas. They reported that the downstream ammonium ion concentration was bigger than the upstream, that is, being influenced by agriculture and urbanization. They found a higher concentration of humic substances in the downstream sections that were positively related to the forested area that was contained in the fluviometric section.

The nitrate ion in FS1 showed a decrease in its upper limit, from 7.8 to $7.0 \mathrm{mg} . \mathrm{L}^{-1}$ and median of 3.8 to $3.2 \mathrm{mg} . \mathrm{L}^{-1}$, the first and third quartile in rainy periods (Figure $5 \mathrm{E}$ ). There is a statistical difference between the dry and rainy periods for the nitrate ion, which was not expected. This is because the ammonium ion in water tends to be oxidized to nitrite and further to nitrate ion, however, there is no statistical difference in ammonium ion, as previously reported.

The behavior of decreased concentration of nitrate ion during rainy periods can be attributed to the dilution effect caused by the superficial runoff generated by rainfall and contributing to the water into the river with low nitrate ion concentration. As described by Neal et al. (2012) in their high frequency monitoring, the nitrate ion in general decreased the concentrations, which decreased with increasing flow, presenting a complex relation.

It may have also occurred at the entrance hysteresis and limited transport nitrate ion, as Outram et al. (2014) found in their high frequency monitoring work of nitrogen in three watersheds of rural use in England. The authors expected that nitrate ion transport was exacerbated by earlier dry conditions of the heavy rain, which did not occur.

In the rainy period, the turbidity of FS2 had its high upper limit from 140 to 160 NTU. There was also a slight increase in the median and Q3 (Figure 5F). In FS1, the turbidity had a little change. However, it was noticed that an increase of the upper limit on rainy times, as compared with the dry, is a statistically significant difference (Figure 5F). Turbidity of FS1 showed lower values of FS2, so much in dry and rainy periods.

The FS2 presented some high turbidity spikes (Figure 4K) in the dry and rainy periods. Some high levels of turbidity found in FS2, especially in the dry period, can be attributed to the extraction of sand that occurs in the river. The extraction takes place in the Santo Amaro da Imperatriz region where there is soil disaggregation, although there is a city law prohibiting the use of this equipament (CASAN, 2002; G1, 2015). This practice increases the particulate matter, causing dispersion and reflection of the light rays passing through the water (FERNANDO et al., 2008). According to Sacramento (2015), in a consultation with the Secretaria de Desenvolvimento Sustentável do Estado de Santa Catarina, there are three dredges operating in Cubatão do Sul River for sand extraction. The author worked with the hourly average turbidity in Cubatão do Sul River and found the peak of this parameter between 6 and 7 p.m. Sacramento (2015) attributed this increase in turbidity to suspended sediments from the extraction of sand, since after the extractors ceased activity, the suspended matter reduced its concentration at the sampling point. After this peak, the time average turbidity falls and remains at low values up to $10 \mathrm{a} . \mathrm{m}$. During the night and early morning, in a time step of approximately 10 hours, there is a decrease in turbidity from 80 to 40 NTU.

For both FS1 and FS2, an increase in turbidity occurred in rainy periods, as found by Saraceno et al. (2009), who worked with high frequency monitoring in situ during short rain. He noticed that the peak of turbidity occurred 4 hours before the peak of discharge. A similar response was found by Bieroza and Heathwaite (2015) who worked with 61 intense rainfall events and used high frequency monitoring in situ in a watershed with predominant use of pasture. The authors found that for all heavy rainfall events there was increased turbidity with the magnitude varying according to the gradient of heavy rain, ranging from 2 to 5 orders.

The values of turbidity of FS2 showed higher values than those of FS1, both in dry and rainy periods (Figure 5F), a fact that can be attributed to the difference of land use and occupation of each fluviometric section. FS2 is influenced by two urbanized areas, which consequently have suppression of vegetation and bare soil for engineering works. Additionally, there is agricultural activity, which involves activities with the soil such as non-perennial crops and livestock that increase soil compaction and reduces rainwater infiltration. Due to exposed soil and larger areas waterproofed from urbanization, there is an increase of superficial runoff with particle entrainment causing the increase of turbidity of the water of FS2.

The study by Esteves, Lôbo and Hilsdorf (2015) in a humid area in Brazil showed that the condition of the river is affected by land use within a sub-watershed. The average turbidity found in areas of native or secondary forest was 16.27 and 14.60 NTU, respectively. In areas of pastures and eucalyptus planting, the values increased significantly, 61.67 and 31.31 NTU. In preserved areas, which is most of FS1, turbidity values were lower than in areas used for agriculture as in the case of FS2.

The dissolved oxygen of FS1 in the lower and upper limits were slightly enlarged during rainy periods (Figure 5G), and an increase in Q3 from 9.10 to 9.25 mg. $\mathrm{L}^{-1}$. The median was also increased between the dry and rainy periods. 
This expansion of the minimum and maximum dissolved oxygen found in FS1 in the rainy period has the same behavior found by Moraetis et al. (2010) who observed the changing of the amplitude of the dissolved oxygen through high frequency monitoring after the heavy rainfall events. The concentration gradually increased after the rainfall.

The increase in the concentration of dissolved oxygen can be attributed to the increase of turbulence in the river flow, while the decrease in concentration can be caused by oxidation of organic matter. There is increased organic matter decomposition upstream of FS1, which may have undergone oxidation in water and decreased the concentration of dissolved oxygen. Chiba de Castro, Cunha-Santino and Bianchini Junior (2013) reported that having changes in the ecosystem that increase the availability of nutrients would reduce the availability of dissolved oxygen.

In FS2, the dissolved oxygen showed opposite behavior, decreasing their lower limits, from 7.1 to $8.0 \mathrm{mg} \cdot \mathrm{L}^{-1}$, and higher in the rainy period compared to the dry, although no statistically significant difference was detected (Figure 5G). FS2 has more oxygenate than FS1 for both rainy and dry periods.

Saraceno et al. (2009) evaluated the water dynamic of the surface in an agricultural watershed over a four-week period containing rain events of short duration. They showed that the dissolved oxygen has a diurnal variability in the pre and post event, even with low concentrations during the rainy period. Similar behavior was expected for FS2, as mentioned in the study, which also has agricultural contribution.

\section{CONCLUSION}

This study found that the water quality of the Cubatão do Sul watershed is influenced by the river flow with short-term response due to rain events.

Retention curves plotted for the dry and rainy periods showed similar behavior in FS1 to the parameters temperature, electrical conductivity, $\mathrm{pH}$, ammonium ion, nitrate ion and turbidity. FS2 presented a similar behavior only for the temperature curve, ammonium ion and turbidity parameters. It is concluded that the quality of the water maintains a more uniform behavior between rainy and dry periods in preserved areas when compared to urban and rural areas.

All parameters analyzed showed different behavior between the sections. Moreover, the temperature, conductivity and turbidity showed different behavior between the dry and rainy periods. The $\mathrm{pH}$, ammonium ion and dissolved oxygen from FS2 and only the ammonium ion of FS1 showed no difference in the measured values between the dry and rainy periods, although there was a statistical difference between the rainy and dry periods in 6 of the 7 parameters studied for FS1 and in 3 of 6 for FS2. It is clear that in the oscillation between parameters values in the two periods (dry and rainy), the variation is lower in a preserved area with native forest compared to the one with the land use in urban and rural occupation.

\section{ACKNOWLEDGEMENTS}

The authors thank FAPESC (Terms Grant 17419 / 2011-0) and CNPq (process 403739 / 2013-6 and 303472/2014/6) for financial support, and CAPES for the grant for a Master's student.

\section{REFERENCES}

ALMEIDA, D. L.; BENASSI, R. F. Crise hídrica e de energia elétrica entre 2014-2015 na região Sudeste. Revista Hipótese. Itapetininga, v. 1, n. 2, p. 65-76, 2015.

ANDRADE, T. M. B.; CAMARGO, P. B.; SILVA, D. M. L.; PICCOLO, M. C.; VIEIRA, S. A.; ALVES, L. F.; JOLY, C. A.; MARTINELLI, L. A. Dynamics of Dissolved Forms of Carbon and Inorganic Nitrogen in Small Watersheds of the Coastal Atlantic Forest in Southeast Brazil. Water, Air, and Soil Pollution, v. 214, n. 1-4, p. 393-408, 2011. http://dx.doi.org/10.1007/s11270-010-0431-z.

AUBERT, A. H.; KIRCHNER, J. W.; GASCUEL-ODOUX, C.; FAUCHEUX, M.; GRUAU, G.; MÉROT, P. Fractal water quality fluctuations spanning the periodic table in an intensively farmed watershed. Environmental Science \& Technology, v. 48, n. 2, p. 930-937, 2014. http://dx.doi.org/10.1021/es403723r. PMid:24328425.

BACK, Á. J. Chuvas intensas e chuva de projeto de drenagem superficial no Estado de Santa Catarina. Florianópolis: Epagri, 2002. 65 p. (Boletim de Pesquisa e Desenvolvimento, 123).

BIEROZA, M. Z.; HEATHWAITE, A. L. Seasonal variation in phosphorus concentration-discharge hysteresis inferred from high-frequency in situ monitoring. Journal of Hydrology, v. 524, p. 333-347, 2015. http://dx.doi.org/10.1016/j.jhydrol.2015.02.036.

BRION, G.; BRYE, K. R.; HAGGARD, B. E.; WEST, C.; BRAHANA, J. V. Land-use effects on water quality of a firstorder stream in the Ozark highlands, mid-southern United States. River Research and Applications, v. 27, n. 6, p. 772-790, 2011. http:// dx.doi.org/10.1002/rra.1394.

CARNAVAL, A. C.; HICKERSON, M. J.; HADDAD, C. F. B.; RODRIGUES, M. T.; MORITZ, C. Stability predicts genetic diversity in the Brazilian Atlantic Forest Hotspot. Science, v. 323, n. 5915, p. 785-789, 2009. http://dx.doi.org/10.1126/science.1166955. PMid:19197066.

CASAN - COMPANHIA CATARINENSE DE ÁGUAS E SANEAMENTO. Expedição ao Rio Cubatão. Santa Catarina, 2002. Available from: <http://www.casan.com.br/menu-conteudo/ index/url/expedicao-ao-rio-cubatao\#0>. Access on: 27 oct. 2015.

CASSON, N. J.; EIMERS, M. C.; WATMOUGH, S. A. Sources of nitrate export during rain-on-snow events at forested catchments. Biogeochemistry, v. 120, n. 3, p. 23-36, 2014. http://dx.doi.org/10.1007/ s10533-013-9850-4.

CHIBA DE CASTRO, W.; CUNHA-SANTINO, M. B.; BIANCHINI JUNIOR, I. Anaerobic decomposition of a native and an exotic submersed macrophyte in two tropical reservoirs. Brazilian Journal of Biology = Revista Brasileira de Biologia, v. 73, n. 2, p. 299-307, 2013. http://dx.doi.org/10.1590/S1519-69842013000200010.

CURTARELLI, M. P. SIG aplicado à caracterização morfométrica de bacias hidrográficas: estudo de caso da bacia hidrográfica do rio 
Cubatão do Sul - Santa Catarina/Brasil. In: SIMPÓSIO BRASILEIRO DE SENSORIAMENTO REMOTO, 14., 2009, Natal. Anais... Natal: INPE, 2009. p. 4693-4699. Available from: < http:/ / marte. sid.inpe.br/col/dpi.inpe.br/sbsr\%04080/2008/11.17.23.06.25/ doc/4693-4699.pdf?languagebutton=en>. Access on: 18 aug. 2014.

DINIZ, A. R.; PEREIRA, M. G.; BALIEIRO, F. D. C.; MACHADO, D. L.; MENEZES, C. E. G. Precipitação e aporte de nutrientes em diferentes estúdios sucessionais de floresta Atlântica, Pinheiral - RJ. Ciência Florestal, v. 23, n. 3, p. 389-399, 2013. http://dx.doi. org/10.5902/1980509810550.

EMBRAPA - EMPRESA BRASILEIRA DE PESQUISA AGROPECUÁRIA. Cultivo de tomate para industrialização: adubação. Brasília: Embrapa Hortaliças, 2006. Versão Eletrônica. (Sistemas de Produção). Available from: <https://sistemasdeproducao. cnptia.embrapa.br/FontesHTML/Tomate/TomateIndustrial_2ed/ adubacao.htm>. Access on: 22 feb. 2016.

ESTEVES, K. E.; LÔBO, A. V. P.; HILSDORF, A. W. S. Abiotic features of a river from the Upper Tietê River Basin (SP, Brazil) along an environmental gradient. Acta Limnologica Brasiliensia, v. 27, n. 2, p. 228-237, 2015. http://dx.doi.org/10.1590/S2179-975X5914.

FATMA - FUNDAÇÃO DO MEIO AMBIENTE. Parque Estadual da Serra do Tabuleiro. Florianópolis, 2015. Available from: <http:// www.fatma.sc.gov.br/conteudo/parque-estadual-da-serra-dotabuleiro >. Access on: 29 sept. 2015.

FERNANDO, A.; LEONARDO, G.; TACHIBANA, L.; CORRÊA, C. F.; KOKI, M. R.; LOBO NETO, A.; BACCARIN, A. E. Qualidade da água do rio ribeira de Iguapé da área de extração de areia no município de Registro, SP. Revista Acadêmica de Ciências Agrárias e Ambientais, v. 6, n. 4, p. 483-492, 2008.

FUJII, K.; HARTONO, A.; FUNAKAWA, S.; UEMURA, M.; SUKARTININGSIH; KOSAKI, T. Acidification of tropical forest soils derived from serpentine and sedimentary rocks in East Kalimantan, Indonesia. Geoderma, v. 160, n. 3-4, p. 311-323, 2011. http://dx.doi.org/10.1016/j.geoderma.2010.09.027.

G1. Santa Catarina. Extraşão de areia no Rio Cubatão ameaça gravemente o ecossistema da região. 3 out. 2015. Available from: <http://g1.globo. $\mathrm{com} / \mathrm{sc} /$ santa-catarina/jornal-do-almoco/videos/t/florianopolis/v/ extracao-de-areia-no-rio-cubatao-ameaca-gravemente-o-ecossistemada-regiao/4512460/>. Access on: 9 oct. 2015.

HALLIDAY, S. J.; SKEFFINGTON, R. A.; WADE, A. J.; BOWES, M. J.; GOZZARD, E.; NEWMAN, J. R.; LOEWENTHAL, M.; PALMER-FELGATE, E. J.; JARVIE, H. P. High-frequency water quality monitoring in an urban catchment: hydrochemical dynamics, primary production and implications for the Water Framework Directive. Hydrological Processes, v. 29, p. 3388-3407, 2015. http:/ / dx.doi.org/10.1002/hyp.10453.

HALLIDAY, S.; SKEFFINGTON, R.; BOWES, M.; GOZZARD, E.; NEWMAN, J.; LOEWENTHAL, M.; PALMER-FELGATE, E.; JARVIE, H.; WADE, A. The water quality of the River
Enborne, UK: observations from high-frequency monitoring in a rural, lowland river system. Water, v. 6, n. 1, p. 150-180, 2014. http://dx.doi.org/10.3390/w6010150.

IBGE - INSTITUTO BRASILEIRO DE GEOGRAFIA E ESTATÍSTICA. Santa Catarina: Santo Amaro da Imperatriz, Águas Mornas. Rio de Janeiro, 2015. Available from: <http:// cidades.ibge.gov.br/xtras/home.php>. Access on: 29 sept. 2015.

KAMJUNKE, N.; BÜTTNER, O.; JÄGER, C. G.; MARCUS, H.; VON TÜMPLING, W.; HALBEDEL, S.; NORF, H.; BRAUNS, M.; BABOROWSKI, M.; WILD, R.; BORCHARDT, D.; WEITERE, M. Biogeochemical patterns in a river network along a land use gradient. Environmental Monitoring and Assessment, v. 185, n. 11, p. 9221-9236, 2013. http://dx.doi.org/10.1007/s10661-013-3247-7. PMid:23780728.

KOBIYAMA, M.; CHAFFE, P. L. B. Water balance in Cubatão-Sul river catchment, Santa Catarina, Brazil. Revista Ambiente e Agua. Taubaté, v. 3, n. 1, p. 5-17, 2008.

MIRANDA, C. C.; CANELLAS, L. P.; NASCIMENTO, M. T. Caracterização da matéria orgânica do solo em fragmentos de mata atlântica e em plantios abandonados de eucalipto. Revista Brasileira de Ciencia do Solo, v. 31, n. 1, p. 905-916, 2007. http:// dx.doi.org/10.1590/S0100-06832007000500008.

MORAETIS, D.; EFSTATHIOU, D.; STAMATI, F; TZORAKI, O.; NIKOLAIDIS, N. P.; SCHNOOR, J. L.; VOZINAKIS, K. High-frequency monitoring for the identification of hydrological and bio-geochemical processes in a Mediterranean river basin. Journal of Hydrology, v. 389, n. 1-2, p. 127-136, 2010. http://dx.doi. org/10.1016/j.jhydrol.2010.05.037.

MYERS, N.; MITTERMEIER, R. A.; MITTERMEIER, C. G.; DA FONSECA, G. A.; KENT, J. Biodiversity hotspots for conservation priorities. Nature, v. 403, n. 6772, p. 853-858, 2000. http://dx.doi.org/10.1038/35002501. PMid:10706275.

NEAL, C.; REYNOLDS, B.; ROWLAND, P.; NORRIS, D.; KIRCHNER, J. W.; NEAL, M.; SLEEP, D.; LAWLOR, A.; WOODS, C.; THACKER, S.; GUYATT, H.; VINCENT, C.; HOCKENHULL, K.; WICKHAM, H.; HARMAN, S.; ARMSTRONG, L.. Highfrequency water quality time series in precipitation and streamflow: From fragmentary signals to scientific challenge. The Science of the Total Environment, v. 434, p. 3-12, 2012. http://dx.doi.org/10.1016/j. scitotenv.2011.10.072. PMid:22245159.

NEAL, C.; ROBINSON, M.; REYNOLDS, B.; NEAL, M.; ROWLAND, P.; GRANT, S.; NORRIS, D.; WILLIAMS, B.; SLEEP, D.; LAWLOR, A. Hydrology and water quality of the headwaters of the River Severn: Stream acidity recovery and interactions with plantation forestry under an improving pollution climate. The Science of the Total Environment, v. 408, n. 21, p. 5035-5051, 2010. http:// dx.doi.org/10.1016/j.scitotenv.2010.07.047. PMid:20708776.

OUTRAM, F. N.; LLOYD, C. E. M.; JONCZYK, J.; BENSKIN, C. M. H.; GRANT, F.; PERKS, M. T.; DEASY, C.; BURKE, S. P.; 
COLLINS, A. L.; FREER, J.; HAYGARTH, P. M.; HISCOCK, K. M.; JOHNES, P. J.; LOVETT', A. L. High-frequency monitoring of nitrogen and phosphorus response in three rural catchments to the end of the 2011-2012 drought in England. Hydrology and Earth System Sciences, v. 18, n. 9, p. 3429-3448, 2014. http://dx.doi. org/10.5194/hess-18-3429-2014.

PRUSKI, F. F.; BOF, L. H. N.; SILVA, L. M. C.; SILVA, J. M. A.; REGO, F. S.; JUSTINO, F. B. Impact of the substitution of reference annual streamflow by monthly streamflow on the potential use of water resources. Engenharia Agricola. Jaboticabal, v. 34, n. 3, p. 496-509, 2014.

REX, J. F.; MALONEY, D. A.; KRAUSKOPF, P. N.; BEAUDRY, P. G.; BEAUDRY, L. J. Variable-retention riparian harvesting effects on riparian air and water temperature of sub-boreal headwater streams in British Columbia. Forest Ecology and Management, v. 269, p. 259-270, 2012. http://dx.doi.org/10.1016/j.foreco.2011.12.023.

RIAZ, M.; MIAN, I. A.; CRESSER, M. S. How important is plant litter to the regulation of mineral-N leaching to streams in winter? An observations-led experimental approach. Soil Use and Management, v. 27, n. 3, p. 10-17, 2011. http://dx.doi. org/10.1111/j.1475-2743.2010.00306.x.

SACRAMENTO, D. L. P. Utilização de ferramentas de gestão ambiental para a melhoria da Qualidade do Rio Cubatão (Santa Catarina). 2015. 69 p. Monografia (Trabalho de Conclusão de Curso em Engenharia Sanitária e Ambiental) - Universidade Federal de Santa Catarina, Florianópolis, 2015.

SARACENO, J. F.; PELLERIN, B. A.; DOWNING, B. D.; BOSS, E.; BACHAND, P. A. M. High-frequency in situ optical measurements during a storm event: Assessing relationships between dissolved organic matter, sediment concentrations, and hydrologic processes. Journal of Geophysical Research. Biogeosciences, v. 114, p. 1-11, 2009.

SERGIO, D. Z.; FRANCO, D.; GARBOSSA, L. H. P. Modelagem Hidrológica da Bacia do Rio Cubatão do Sul com o modelo SWAT - Soil and water assessment tool. In: SIMPÓSIO BRASILEIRO DE RECURSOS HÍDRICOS, 20., 2013, Bento Gonçalves. Anais... Bento Gonçalves: ABRH, 2013. Available from: <https://www. abrh.org.br/sgcv3/UserFiles/Sumarios/634ab4a58d4d395f73 f200023aa63e8a_bd09993a7e424dbd1 ceb0119c0411fbf.pdf > . Access on: 18 aug. 2014.
TERCIER-WAEBER, M.-L.; HEZARD, T.; MASSON, M.; SCHÄFER, J. In situ monitoring of the diurnal cycling of dynamic metal species in a stream under contrasting photobenthic biofilm activity and hydrological conditions. Environmental Science \& Technology, v. 43, n. 19, p. 7237-7244, 2009. http://dx.doi. org/10.1021/es900247y. PMid:19848128.

VISWANATHAN, V. C.; MOLSON, J.; SCHIRMER, M. Does river restoration affect diurnal and seasonal changes to surface water quality? A study along the Thur River, Switzerland. The Science of the Total Environment, v. 532, p. 91-102, 2015. http://dx.doi. org/10.1016/j.scitotenv.2015.05.121. PMid:26057997.

WADE, A. J.; PALMER-FELGATE, E. J.; HALLIDAY, S. J.; SKEFFINGTON, R. A.; LOEWENTHAL, M.; JARVIE, H. P.; BOWES, M. J.; GREENWAY, G. M.; HASWELL, S. J.; BELL, I. M.; JOLY, E.; FALLATAH, A.; NEAL, C.; WILLIAMS, R. J.; GOZZARD, E.; NEWMAN, J. R. Hydrochemical processes in lowland rivers: insights from in situ, high-resolution monitoring. Hydrology and Earth System Sciences, v. 16, n. 11, p. 4323-4342, 2012. http://dx.doi.org/10.5194/hess-16-4323-2012.

XI, M.; KONG, F.; LYU, X.; JIANG, M.; LI, Y. Spatial variation of dissolved organic carbon in soils of riparian wetlands and responses to hydro-geomorphologic changes in Sanjiang Plain, China. Chinese Geographical Science, v. 25, n. 2, p. 174-183, 2015. http://dx.doi.org/10.1007/s11769-015-0744-3.

\section{Authors contributions}

Rubia Girardi: Responsible for the paper structure, writing and data processing.

Adilson Pinheiro: Advisor professor who supervised the research and suggested improvements in the paper structure, writing and results.

Luis Hamilton Pospissil Garbossa: Responsible for collecting field data. Co-advisor of the student who contributed in the paper structure.

Edson Torres: Contributions to the paper structure and writing. 